\title{
Microbial Reduction and Detoxification of Chromium from Tannery Effluent by Natural Inhabitants
}

\author{
Sawkat Ara Pinki*(**), Md. Reazul Karim*, Dipankar Dewanjee*, Habibur Rahman Bhuiyan***, H. M. Abdullah \\ Al Masud* and Md. Imranul Hoq*† \\ *Department of Microbiology, Faculty of Biological Sciences, University of Chittagong, Chattogram-4331, Bangladesh \\ **National University, Gazipur-1704, Bangladesh \\ ***Industrial Microbiology Research Division, Bangladesh Council of Scientific and Industrial Research, \\ Chattogram-4220, Bangladesh \\ †Corresponding Author: Md. Imranul Hoq; imran.mbio@cu.ac.bd
}

Nat. Env. \& Poll. Tech.

Website: www.neptjournal.com

Received: 12-10-2020

Revised: $04-12-2020$

Accepted: 08-12-2020

Key Words:

Industrial waste

Tannery effluent

Chromium

Hexavalent chromium

Detoxification

Bioremediation

\begin{abstract}
Chromium (Cr), a chemical agent, has long been used extensively in leather tanning. Hexavalent chromium $(\mathrm{Cr}-\mathrm{VI})$ found in tannery effluent is highly toxic, carcinogenic and mutagenic to humans. Transformation of $\mathrm{Cr}-\mathrm{VI}$ to its trivalent counterpart, $\mathrm{Cr}-\mathrm{III}$, is the basic process in its detoxification, and microbial transformation of $\mathrm{Cr}-\mathrm{VI}$ to $\mathrm{Cr}$-III has been one of the most widely studied forms of $\mathrm{Cr}$ bioremediation. This study aims to explore the ability of naturally occurring bacteria in reducing and detoxifying $\mathrm{Cr}$ in vitro and also from tannery effluent. Five efficient $\mathrm{Cr}$ reducing and detoxifying bacteria were isolated from tannery effluent, their morphological, cultural, physiological and biochemical characteristics investigated. They were identified as Aeromonas eucrenophila, Bacillus megaterium, $B$. carboniphilus, $B$. licheniformis and $B$. subtilis. Coincubation of the isolates with varying concentrations of potassium dichromate $\left(\mathrm{K}_{2} \mathrm{Cr}_{2} \mathrm{O}_{7}\right)$, a $\mathrm{Cr}$ salt, in minimum salts medium, $\mathrm{pH} 7$ revealed notable reduction and detoxification of $\mathrm{Cr}$ within 24-72 $\mathrm{h}$ as determined by 1,5-diphenylcarbazide colorimetric method and atomic absorption spectrophotometry, respectively. The isolates exhibited substantial resistance or tolerance to 125 to $500 \mathrm{ppm} \mathrm{K} \mathrm{K}_{2} \mathrm{Cr}_{2} \mathrm{O}_{7}$. Bacterial detoxification or reduction of was increasingly increased as the incubation period increased from 24 to 48 or $72 \mathrm{~h}$ and substrate concentration increased from 125 to 250 or $500 \mathrm{ppm}$. Most of the isolates exhibited increased reduction and detoxification at $37^{\circ} \mathrm{C}$ compared to that at $30^{\circ} \mathrm{C}$ or $45^{\circ} \mathrm{C}$, and at $\mathrm{pH} 7$ or 8 compared to that at $\mathrm{pH} 5$ or 6 . Furthermore, all the isolates exhibited highest detoxification or reduction when peptone was used as carbon source instead of glucose or ammonium acetate. In a chosen or optimized condition of $37^{\circ} \mathrm{C}$ temperature, $\mathrm{pH} 7,125$ ppm $\mathrm{K}_{2} \mathrm{Cr}_{2} \mathrm{O}_{7}$ concentration and $48 \mathrm{~h}$ incubation period, most isolates exhibited $85-99 \% \mathrm{Cr}$ reduction and detoxification from tannery effluent. It was, therefore, inferred that the isolates have potential as biological agent in reducing and detoxifying $\mathrm{Cr}$ from industrial effluent.
\end{abstract}

\section{INTRODUCTION}

Industrial pollution is a major factor to cause significant degradation to the environment around us. Since industrialization is continuously growing worldwide, in the present time, industrial wastes play the most common source of water pollution (Ogedengbe \& Akinbile 2004). In a developing country like Bangladesh, solid waste or effluent from a tannery is directly discharged into water bodies or sewers without treatment (Verheijen et al. 1996; Favazzi 2002). Hence, tannery wastewater is thus found extremely polluted in terms of total dissolved solids (TDS), total suspended solids (TSS), biochemical oxygen demand (BOD), chemical oxygen demand (COD), heavy metals, etc. (Mondal et al. 2005). In Bangladesh, tanning industries are one of the main economic activities. Bangladesh now has 165 leather and footwear factories. Furthermore, it has 161 tanning industries that process rawhides into finished leather. The vast majority of these industries are located in and around Dhaka, whilst a very few are scattered all over the country (Gain \& Moral 1999). A very recent study has expressed an estimation that a total of 232-ton solid waste and 20-millionliter wastewater are produced every day from these industries (Saha \& Azam 2021). In the tanning industries, extensive use of $\mathrm{Cr}$ in the chrome tanning process results in the release of $\mathrm{Cr}$ that contaminates soil and water at production sites (Turick et al. 1996). The solid waste or wastewater discharged from the tanneries contains substantial amount of $\mathrm{Cr}$ (Franco et al. 2005). Cr is a highly toxic heavy metal and is known to be mutagenic, carcinogenic and teratogenic to humans, animals and plants. However, Cr exists in nature in various oxidation states ranging from divalent to hexavalent ones. $\mathrm{Cr}$-III and $\mathrm{Cr}$-VI are the most stable states, and the biological, toxicological and geochemical properties of them 
vary remarkably. Cr-VI is known to be much more toxic than $\mathrm{Cr}$-III for multiple reasons. In nature, $\mathrm{Cr}$-III exists at a narrow range of concentration, and is an essential element because it regulates the metabolism of glucose in human body (Srinath et al. 2001). In contrast, Cr-VI is highly soluble in water, rapidly permeable through biological membranes, and prone to subsequently interact with intracellular proteins and nucleic acids. Cr-VI interacts with DNA quite indirectly, and exhibits genotoxicity via reactive intermediates produced during its intracellular reduction to Cr-III. The types of DNA damage caused by $\mathrm{Cr}-\mathrm{VI}$ is thereby grouped into two major categories: oxidative DNA damage and Cr-IIIDNA interaction (Sobol \& Schiestl 2012). Even at very low concentration, $\mathrm{Cr}-\mathrm{VI}$ is highly toxic and hazardous to human health. Other than $\mathrm{Cr}$, the most commonly occurring heavy metals in tannery wastewater include lead, manganese, cadmium and copper. Occurrence of these toxic substances in surface water and soil leads to serious public health threat and significant risk to the ecological system (Sundar et al. 2010). The present study thus aims to investigate the ability of naturally occurring bacteria in reducing and detoxifying $\mathrm{Cr}$ at privileged nutritional and environmental conditions, and evaluate their potentiality as candidate agent of bioremediation of the heavy metal.

\section{MATERIALS AND METHODS}

\section{Collection of Sample}

Tannery effluent samples were collected in sterile plastic bottles from RIFF Leather Industries, Kalurghat Industrial Area, Chattogram, Bangladesh. They were immediately placed in an insulated box with frozen refrigerant packs in an insulated box and transported to the laboratory. Other than instant analysis, the samples were preserved at $4^{\circ} \mathrm{C}$ for further analysis.

\section{Isolation of Bacteria from Tannery Effluent}

The nutrient agar medium was used for the isolation of bacteria from the effluent, where the $\mathrm{pH}$ of the medium was adjusted to the $\mathrm{pH}$ of the sample. Pour plate and streak plate techniques were applied for the isolation, and well discrete identical single colonies were picked up and transferred into nutrient agar slants. In case no single colony appeared onto any plate, repeated streaking of the culture was carried out from plate to plate until at least one single colony was appeared. The slants were sealed in polyethylene bags and preserved in a refrigerator at $4^{\circ} \mathrm{C}$ as stock culture for further study. Subculturing at 2-week interval was maintained to keep the physiology and metabolic activity of the isolates unimpaired.

\section{Cr Salt Used for In Vitro Investigation}

Chemical name: Potassium dichromate

Chemical formula: $\mathrm{K}_{2} \mathrm{Cr}_{2} \mathrm{O}_{7}$

Molecular weight: 294

Atomic weight: 52

\section{Screening of Chromium (Cr) Reducing or Detoxifying Bacteria}

The isolates possessing the ability to detoxify or reduce $\mathrm{Cr}$ in vitro were screened by incubating mid logarithmic growing cells of $106 / \mathrm{mL}$ density in varied concentrations of $\mathrm{K}_{2} \mathrm{Cr}_{2} \mathrm{O}_{7}$ supplemented minimal salts medium (MSM) broth base, pH 7 for a substantial period of time (Bibi et al. 2012), and measuring the concentration of residual $\mathrm{Cr}-\mathrm{VI}$ or total $\mathrm{Cr}$, respectively, in the culture supernatant.

\section{Measurement of Cr-VI Concentration}

The concentration of residual Cr-VI in $\mathrm{K}_{2} \mathrm{Cr}_{2} \mathrm{O}_{7}$ supplemented MSM culture supernatant following centrifugation at $4000 \mathrm{rpm}$ for $5 \mathrm{~min}$ was measured by diphenylcarbazide colorimetric method (APHA 1998). In this method, 1,5-diphenylcarbazide (DPC) reagent was used as a colorimetric indicator, which reacted with $\mathrm{Cr}-\mathrm{VI}$ in strongly acidic solution and resulted in the formation of magenta colored carbazone inner complex salt of a chromous ion (Cr-II). The absorbance of the color was measured at 540 $\mathrm{nm}$ in a spectrophotometer (Shimadzu UV-VIS 1800, Japan). In the course of the measurement, a calibration curve was prepared where the standard solution was diluted ranging the concentrations of $0.2-1 \mathrm{ppm}$ by an interval of $0.2 \mathrm{ppm}$. The possible slight loss of $\mathrm{Cr}$ during digestion or other operations of the analysis was compensated by adding no inoculum to the standard solutions but following the same treatment to be applied to the sample. The calibration curve was constructed by plotting the blank-subtracted absorbance of the standard solutions versus respective concentration.

\section{Measurement of Total Cr Concentration}

The concentration of total $\mathrm{Cr}$ in $\mathrm{K}_{2} \mathrm{Cr}_{2} \mathrm{O}_{7}$ supplemented MSM culture supernatant following centrifugation at $4000 \mathrm{rpm}$ for 5 min was measured by atomic absorption spectrophotometry (APHA, WEF, AWWA 1992). In this method, the supernatant was mixed to double volume of concentrated $\mathrm{HNO}_{3}$, and the mixture was heated to $100^{\circ} \mathrm{C}$ by a proper hollow cathode lamp of $10 \mathrm{~mA}$ current on a hot plate in an atomic absorption spectrophotometer (AAS) (Shimadzu AA-7000, Japan) to accomplish acid digestion until the final volume went down to initial supernatant volume. The extract was filtered through a Whatman 42 filter paper to remove any insoluble material, collected into a volumetric flask and diluted. The chrome 
plating operation emitted total $\mathrm{Cr}$, which was quantified by measuring the absorbance at $357.9 \mathrm{~nm}$. In the course of the measurement, a calibration curve was prepared where the standard solution was diluted ranging the concentrations of 1-8 ppm by an interval of $2 \mathrm{ppm}$. The calibration curve was constructed by plotting the blank-subtracted absorbance of the standard solutions versus respective concentration.

\section{Characterization of Cr Detoxifying or Reducing Bacteria}

The bacterial isolates that possessed the ability to reduce or detoxify $\mathrm{Cr}$ following in vitro investigations were subjected to cultural, morphological, physiological and biochemical examinations. Cultural examinations include colony characteristics of the isolates onto nutrient agar plate, i.e., form, color, elevation, margin, surface and their growth pattern onto nutrient agar slant. Morphological examinations include Gram and acid-fast staining of the isolates and microscopic observation of their shape and arrangement. Physiological and biochemical examinations include motility, indole, Voges-Proskauer, methyl red, Simmons citrate, nitrate reduction, triple sugar iron, $\mathrm{H}_{2} \mathrm{~S}$ production, catalase, oxidase and urease tests.

\section{Determination of Bacterial Resistance or Tolerance to $\mathrm{Cr}$}

Bacterial isolates exhibiting substantial ability to reduce or detoxify $\mathrm{Cr}$ were examined to determine their resistance or tolerance to $\mathrm{Cr}$ by a broth dilution method. In this method, mid logarithmic growing cells of 106 cells/mL density were incubated in brain heart infusion broth supplemented with varied concentration of $\mathrm{K}_{2} \mathrm{Cr}_{2} \mathrm{O}_{7}$ for 24 hours at $37^{\circ} \mathrm{C}$ with agitation at $100 \mathrm{rpm}$. The turbidity of the broth, proportionate to bacterial growth, was measured at $600 \mathrm{~nm}$ in a UV-visible spectrophotometer (PG Instruments-UK, Model: T 80+ UVVIS). The isolates that exhibited good to moderate growth at a significant concentration of $\mathrm{Cr}$ salt were considered as resistant or tolerant to $\mathrm{Cr}$.

\section{Determination of Minimum Inhibitory Concentration of Cr Against Bacterial Isolates}

Minimum inhibitory concentration (MIC) of $\mathrm{Cr}$ against the isolates was determined by the broth dilution method described above. In this case, the minimum concentration of $\mathrm{K}_{2} \mathrm{Cr}_{2} \mathrm{O}_{7}$ that prevented visible growth of an isolate was considered as MIC of $\mathrm{Cr}$ against that particular organism.

\section{Determination of Minimum Bactericidal Concentration of Cr Against Bacterial Isolates}

The broth culture of MIC test was applied as inoculum to determine minimal bactericidal concentration (MBC), where $100 \mu \mathrm{L}$ of 18 -h old culture was inoculated by pour plate method to nutrient agar plate. The plate was incubated at $37^{\circ} \mathrm{C}$ and the appearance or absence of growth was observed at $24 \mathrm{~h}$. The minimum concentration that resulted in complete absence of growth onto the plate was considered as MBC.

\section{Determination of Optimum Conditions for Bacterial Detoxification or Reduction of $\mathbf{C r}$}

The efficiency of bacterial isolates in detoxifying or reducing $\mathrm{Cr}$ in vitro were investigated further as described above, whereas variety of conditions applied to determine the optimum ones that include $\mathrm{K}_{2} \mathrm{Cr}_{2} \mathrm{O}_{7}$ concentration in MSM base, incubation period, reaction temperature, medium $\mathrm{pH}$, and additional supplementation of the medium with glucose, peptone or ammonium acetate as carbon source. In every case, a number of pilot experiments were conducted to reveal closely fitted parameters.

\section{Evaluation of Bacterial Detoxification or Reduction of $\mathrm{Cr}$ from Tannery Effluent in Optimized Conditions}

Fresh tannery effluent sample was collected as described above and sterilized by filtration using $0.22 \mu$ filter. The initial concentration of $\mathrm{Cr}-\mathrm{VI}$ and total $\mathrm{Cr}$ in the effluent was determined as described above. The $\mathrm{pH}$ of the sample was adjusted to the optimum for each isolate, inoculated by mid logarithmic growing cells of 106 cells $/ \mathrm{mL}$ density and incubated at optimized temperature for optimized time. The efficiency of the isolates was evaluated by measuring the residual Cr-VI or total $\mathrm{Cr}$ concentration as described above. The data were compared with that obtained under unoptimized conditions.

\section{RESULTS}

\section{Cr Detoxifying or Reducing Ability of Bacterial Isolates from Tannery Effluent}

A total of 16 pure cultures were isolated on nutrient agar slants from the nutrient agar plates following pour and streak plate inoculations of undiluted and diluted tannery effluent samples. The isolates were designated as E1-E16 and investigated for their ability to detoxify or reduce Cr within 24,48 or $72 \mathrm{~h}$ in MSM base, pH 7 supplemented with 125, 250 or 500 ppm $\mathrm{K}_{2} \mathrm{Cr}_{2} \mathrm{O}_{7}$ and incubated at $37^{\circ} \mathrm{C}$. Interestingly, most of the isolates exhibited their ability to detoxify or reduce $\mathrm{Cr}$ in vitro at various time periods or $\mathrm{Cr}$ salt. However, both detoxification of $\mathrm{Cr}$-VI and reduction of total $\mathrm{Cr}$ by the isolates designated as E3, E7, E9, E11 and E14 at $48 \mathrm{~h}$ and 250 ppm $\mathrm{K}_{2} \mathrm{Cr}_{2} \mathrm{O}_{7}$ were remarkable, as plotted in Fig. 1. Hence, these five isolates were considered as potential $\mathrm{Cr}$ detoxifiers or reducers and chosen for further investigations.

\section{Identification of $\mathrm{Cr}$ Detoxifying or Reducing Bacteria}

The cultural, morphological, physiochemical and biochemical 

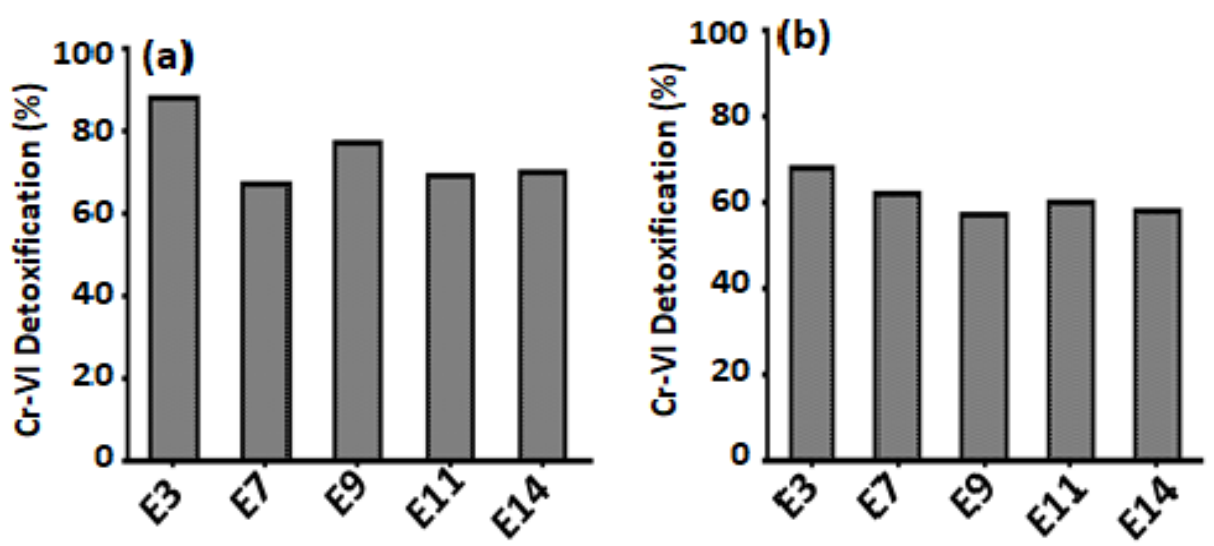

Fig. 1: Detoxification of Cr-VI and reduction of total $\mathrm{Cr}$ by selected isolates from tannery effluent. The experiments were conducted by inoculation of minimal salts medium base, $\mathrm{pH} 7$ supplemented with $250 \mathrm{ppm}$ of $\mathrm{K}_{2} \mathrm{Cr}_{2} \mathrm{O}_{7}$ and incubation at $37^{\circ} \mathrm{C}$ for $48 \mathrm{~h}$ followed by measurement of Cr-VI detoxification (a) by 1,5-diphenylcarbazide colorimetric method and reduction of total $\mathrm{Cr}$ (b) by atomic absorption spectrophotometry.

characteristics of the chosen 5 bacterial isolates that exhibited prominence in detoxifying or reducing $\mathrm{Cr}$, as visualized in Table 1, were compared with the standard descriptions of wild bacteria according to Bergey's manual of determinative bacteriology, 8th (Buchanan \& Gibbsons 1974) and 9th (Goodfeelow et al. 1994) editions. Comparative study revealed that the characteristics of the isolate designated as E3 closely resembled with that of Aeromonas eucrenophila. The isolate E3 was, therefore, identified as Aeromonas eucrenophila. Likewise, through comparative analysis, the isolate E7 was identified as Bacillus megaterium, E9 as Bacillus carboniphilus, E11 as Bacillus licheniformis and E14 as Bacillus subtilis.

\section{Bacterial Resistance or Tolerance to $\mathrm{Cr}$}

In order to evaluate the candidacy of $\mathrm{Cr}$ detoxifying or reducing bacteria as biological agent, we examined their level of resistance or tolerance to $\mathrm{Cr}$ by culturing the isolates in brain heart infusion broth supplemented with various concentrations of $\mathrm{K}_{2} \mathrm{Cr}_{2} \mathrm{O}_{7}$. The isolates exhibited diverse patterns of resistance or tolerance to $\mathrm{Cr}$ as revealed by their level of growth (Fig. 2). For example, the isolate A. eucrenophila exhibited tremendous resistance up to 125 ppm $\mathrm{K}_{2} \mathrm{Cr}_{2} \mathrm{O}_{7}$ concentration, which dramatically reduced when the concentration increased to $250 \mathrm{ppm}$. On the other hand, the other isolates exhibited a dose dependent pattern of resistance with little fluctuations.

\section{MIC and MBC of Cr Against Bacterial Isolates}

The MIC of $\mathrm{Cr}$ against $A$. eucrenophila and B. megaterium was found $125 \mathrm{ppm}$, whereas against $B$. carboniphilus, $B$. licheniformis and B. subtilis, it was found $500 \mathrm{ppm}$. The $\mathrm{MBC}$ of $\mathrm{Cr}$ against all the isolates were found $2000 \mathrm{ppm}$
(Table 2). Fig. 3 visualizes MBC values of A. eucrenophila and B. carboniphilus.

\section{Concentration and Time Dependent Bacterial Detoxifi- cation or Reduction of $\mathbf{C r}$}

The prevailing conditions with regard to $\mathrm{Cr}$ detoxification and reduction by the isolates were investigated in this study. The first attempt was made for $\mathrm{Cr}$ concentration and incubation period. Since the isolates exhibited substantial degree of resistance or tolerance to $125-500 \mathrm{ppm} \mathrm{K}_{2} \mathrm{Cr}_{2} \mathrm{O}_{7}$ and also the MIC values of $\mathrm{K}_{2} \mathrm{Cr}_{2} \mathrm{O}_{7}$ against the isolates ranged from $125-500 \mathrm{ppm}$ at $24 \mathrm{~h}$, we investigated the efficiency of the isolates at 125, 250 and $500 \mathrm{ppm} \mathrm{K}_{2} \mathrm{Cr}_{2} \mathrm{O}_{7}$ at 24, 48 and 72 h. As illustrated in Figs. 4-8, most of the isolates were remarkably efficient in detoxifying or reducing $\mathrm{Cr}$ at all the concentrations applied. Notably, a 2-fold increase in concentration of $\mathrm{K}_{2} \mathrm{Cr}_{2} \mathrm{O}_{7}$ from 125 to 250 did not cause massive variation in their efficiency. The same was observed when the concentration was increased from 250 to $500 \mathrm{ppm}$. In contrast, the efficiency of the isolates was significantly increased when the incubation period was increased from 24 to $48 \mathrm{~h}$, or from 48 to $72 \mathrm{~h}$ at any concentration applied.

\section{Temperature Dependent Bacterial Detoxification or Reduction of $\mathrm{Cr}$}

The effect of temperature on $\mathrm{Cr}$ detoxification or reduction by the bacterial isolates was evaluated at 30,37 and $45^{\circ} \mathrm{C}$ while keeping the concentration of $\mathrm{K}_{2} \mathrm{Cr}_{2} \mathrm{O}_{7}$ as $125 \mathrm{ppm}$ and incubation period as $48 \mathrm{~h}$. Most of the isolates appeared to exhibit maximum level of $\mathrm{Cr}$ detoxification or reduction at $37^{\circ} \mathrm{C}$, and with few exceptions the efficiency of their detoxification or reduction was reduced when the temperature 
Table 1: Cultural, morphological, physiological and biochemical characteristics of Cr detoxifying or reducing bacteria.

\begin{tabular}{|c|c|c|c|c|c|}
\hline \multirow[t]{2}{*}{ Characteristics } & \multicolumn{5}{|c|}{ Observations } \\
\hline & E3 & E7 & E9 & E11 & E14 \\
\hline \multicolumn{6}{|l|}{ Cultural } \\
\hline Colony Form & Circular & irregular & irregular & circular & punctiform \\
\hline Colony Color & Off-white & Off-white & Off-white & cream & cream \\
\hline Colony Elevation & Raised & Flat & Flat & Flat & Convex \\
\hline Colony Margin & Serrate & serrate & erose & entire & entire \\
\hline Colony Surface & Smooth & smooth & smooth & smooth & smooth \\
\hline Slant Character & Echinulate & Echinulate & Echinulate & Filiform & Filiform \\
\hline \multicolumn{6}{|c|}{ Staining and Morphology } \\
\hline Gram Staining & - & + & + & + & + \\
\hline Acid Fast Staining & - & - & - & - & - \\
\hline Shape & Short rod & Short rod & Short rod & Short rod & Short rod \\
\hline Arrangement & Single & Single or pair & Single & Single & Single \\
\hline \multicolumn{6}{|l|}{$\begin{array}{l}\text { Physiological and } \\
\text { Biochemical tests }\end{array}$} \\
\hline Motility test & + & + & - & + & + \\
\hline Indole & + & - & - & - & - \\
\hline Voges-Proskauer & - & - & - & + & - \\
\hline Methyl red & + & + & - & - & - \\
\hline Simmons' citrate & - & + & - & - & + \\
\hline Nitrate Reduction & + & + & - & + & + \\
\hline Catalase & + & + & + & + & + \\
\hline Oxidase & - & + & + & - & + \\
\hline Urease & - & - & - & - & - \\
\hline TSI & $\mathrm{a} / \mathrm{k}$ & $\mathrm{a} / \mathrm{nc}$ & $\mathrm{a} / \mathrm{k}$ & $\mathrm{a} / \mathrm{k}$ & $\mathrm{a} / \mathrm{a}$ \\
\hline $\mathrm{H}_{2} \mathrm{~S}$ production test & - & - & + & - & - \\
\hline
\end{tabular}

+, positive; -, negative; k/a, alkaline slant, acidic butt; a/nc, acidic slant, no change; a/a; acidic slant, acidic butt

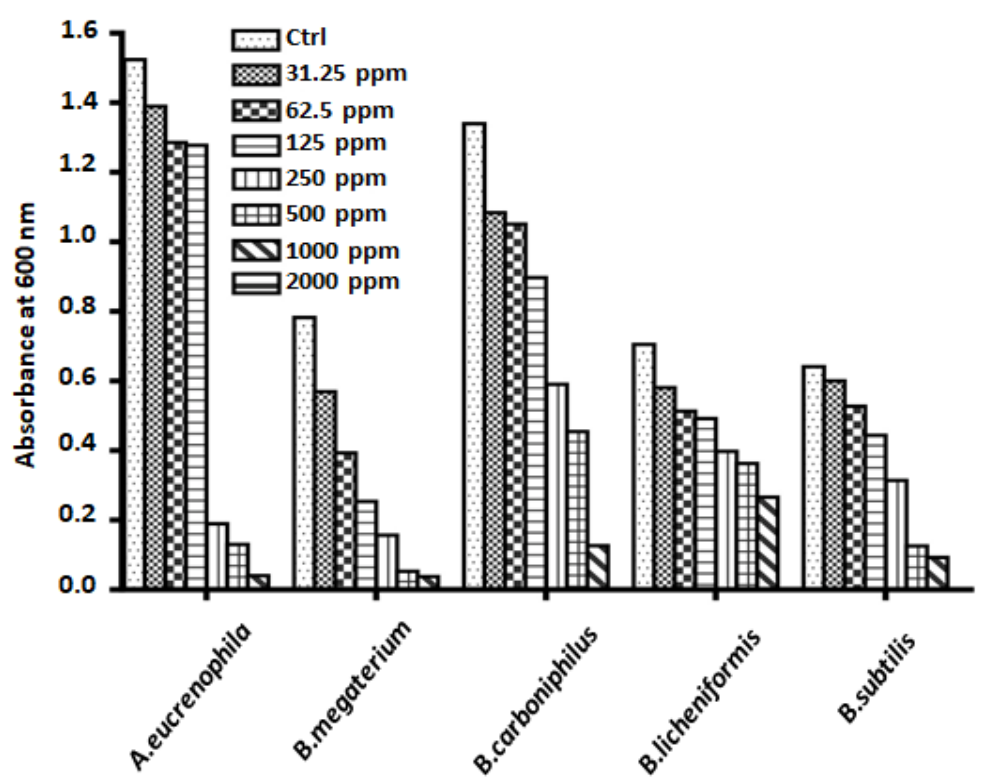

Fig. 2: Resistance or tolerance pattern of bacterial isolates from tannery effluent against $\mathrm{Cr}$. The experiment was conducted by inoculation of brain heart infusion broth supplemented with $31.25,62.5,125,250,500,1000,2000 \mathrm{ppm}$ of $\mathrm{K}_{2} \mathrm{Cr}_{2} \mathrm{O}_{7}$ and incubation at $37^{\circ} \mathrm{C}$ for $24 \mathrm{~h}$ followed by the measurement of turbidity as bacterial growth at $600 \mathrm{~nm}$ in a UV-visible spectrophotometer. 
Table 2: Growth of bacteria from broth dilution minimum inhibitory concentration (MIC) tests onto a nutrient agar plate

\begin{tabular}{|llll|}
\hline Bacteria & \multicolumn{4}{l|}{ Concentration of $\mathrm{K}_{2} \mathrm{Cr}_{2} \mathrm{O}_{7}(\mathrm{ppm})$} \\
\cline { 2 - 4 } & 500 & 1000 & 2000 \\
\hline A. eucrenophila & ++ & + & - \\
B. megaterium & ++ & + & - \\
B. carboniphilus & +++ & + & - \\
B. licheniformis & +++ & ++ & - \\
B. subtilis & ++ & + & - \\
\hline
\end{tabular}

Note: Positive $(+=$ scanty,$++=$ moderate,$+++=$ good $)$, Negative $(-)$
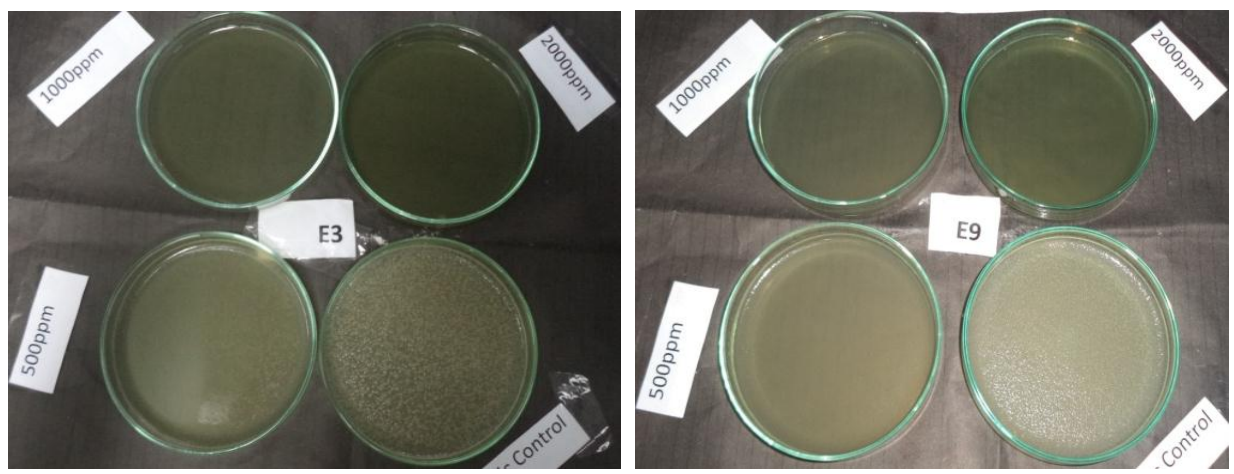

Fig. 3: Growth of (a) A. eucrenophila and (b) B. carboniphilus onto nutrient agar plate inoculated by overnight culture of brain heart infusion broth supplemented with varied concentration of $\mathrm{K}_{2} \mathrm{Cr}_{2} \mathrm{O}_{7}$. The experiment was conducted by inoculation of nutrient agar plate by $18 \mathrm{~h}$ old culture of brain heart infusion broth supplemented with 500, 1000 and $2000 \mathrm{ppm}$ of $\mathrm{K}_{2} \mathrm{Cr}_{2} \mathrm{O}_{7}$ and incubation at $37^{\circ} \mathrm{C}$ for $24 \mathrm{~h}$.

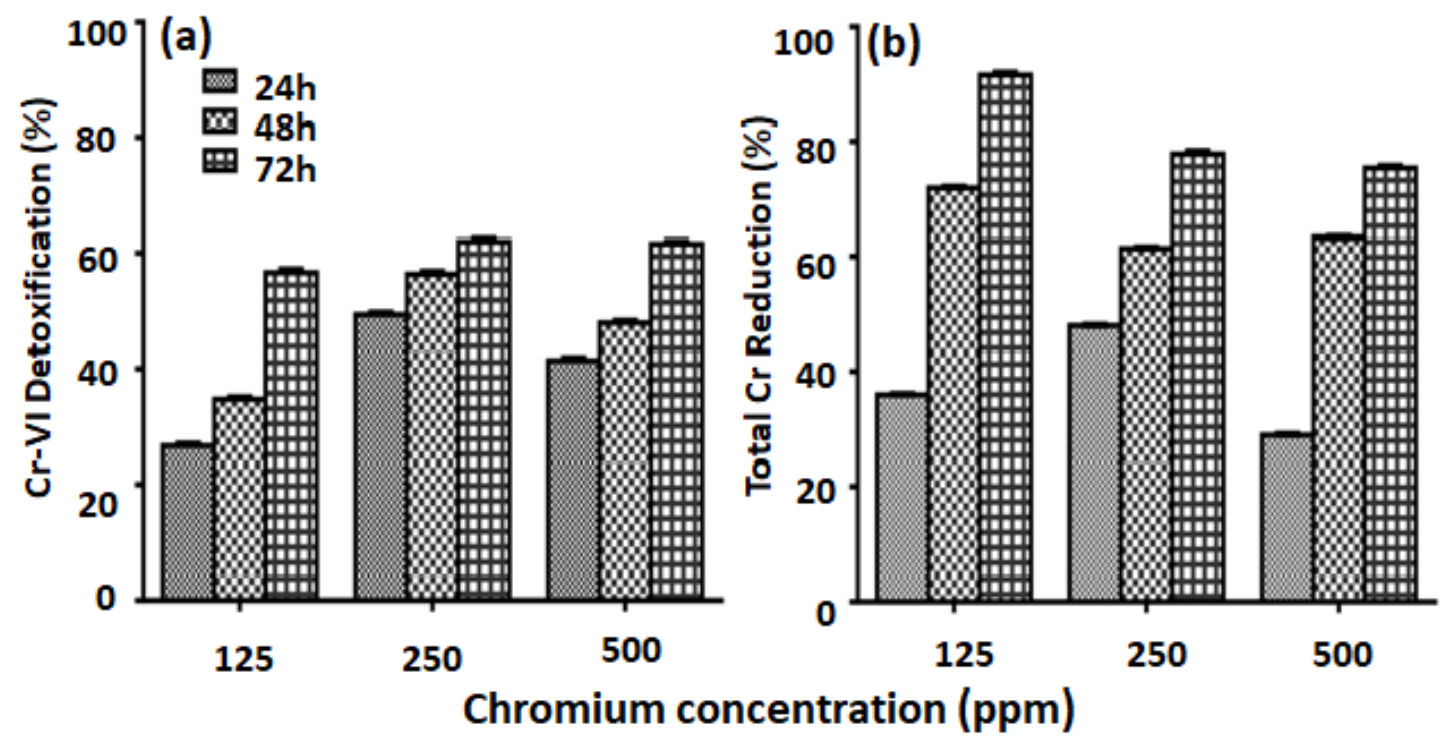

Fig. 4: Detoxification of $\mathrm{Cr}-\mathrm{VI}$ and reduction of total $\mathrm{Cr}$ as $\mathrm{K}_{2} \mathrm{Cr}_{2} \mathrm{O}_{7}$ by A. eucrenophila. The experiments were conducted by inoculation of minimal salts medium base, $\mathrm{pH} 7$ supplemented with 125,250 and 500 ppm of $\mathrm{K}_{2} \mathrm{Cr}_{2} \mathrm{O}_{7}$ and incubation at $37^{\circ} \mathrm{C}$ for 24,48 and $72 \mathrm{~h}$ followed by measurement of Cr-VI detoxification (a) by 1,5-diphenylcarbazide colorimetric method and reduction of total $\mathrm{Cr}$ (b) by atomic absorption spectrophotometry. 


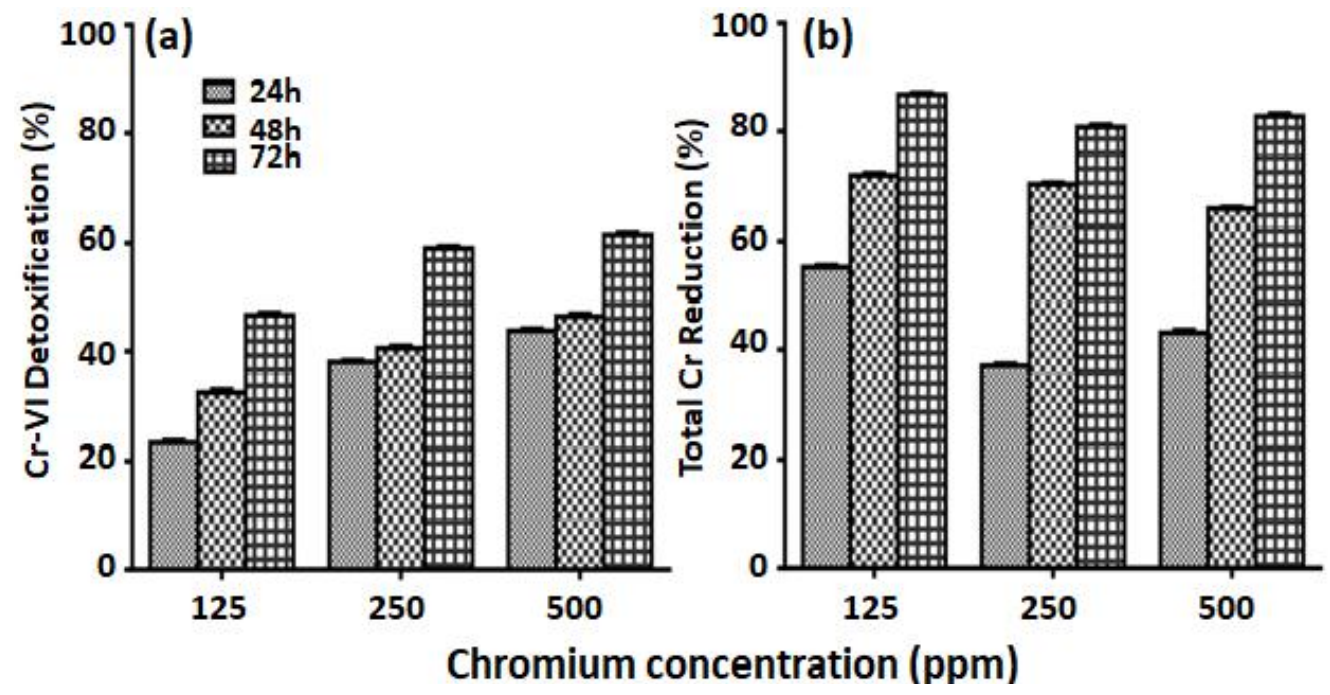

Fig. 5: Detoxification of Cr-VI and reduction of total $\mathrm{Cr}$ as $\mathrm{K}_{2} \mathrm{Cr}_{2} \mathrm{O}_{7}$ by B. megaterium. The experiments were conducted by inoculation of minimal salts medium base, $\mathrm{pH} 7$ supplemented with 125,250 and $500 \mathrm{ppm}$ of $\mathrm{K}_{2} \mathrm{Cr}_{2} \mathrm{O}_{7}$ and incubation at $37^{\circ} \mathrm{C}$ for 24,48 and $72 \mathrm{~h}$ followed by measurement of Cr-VI detoxification (a) by 1,5-diphenylcarbazide colorimetric method and reduction of total $\mathrm{Cr}$ (b) by atomic absorption spectrophotometry.

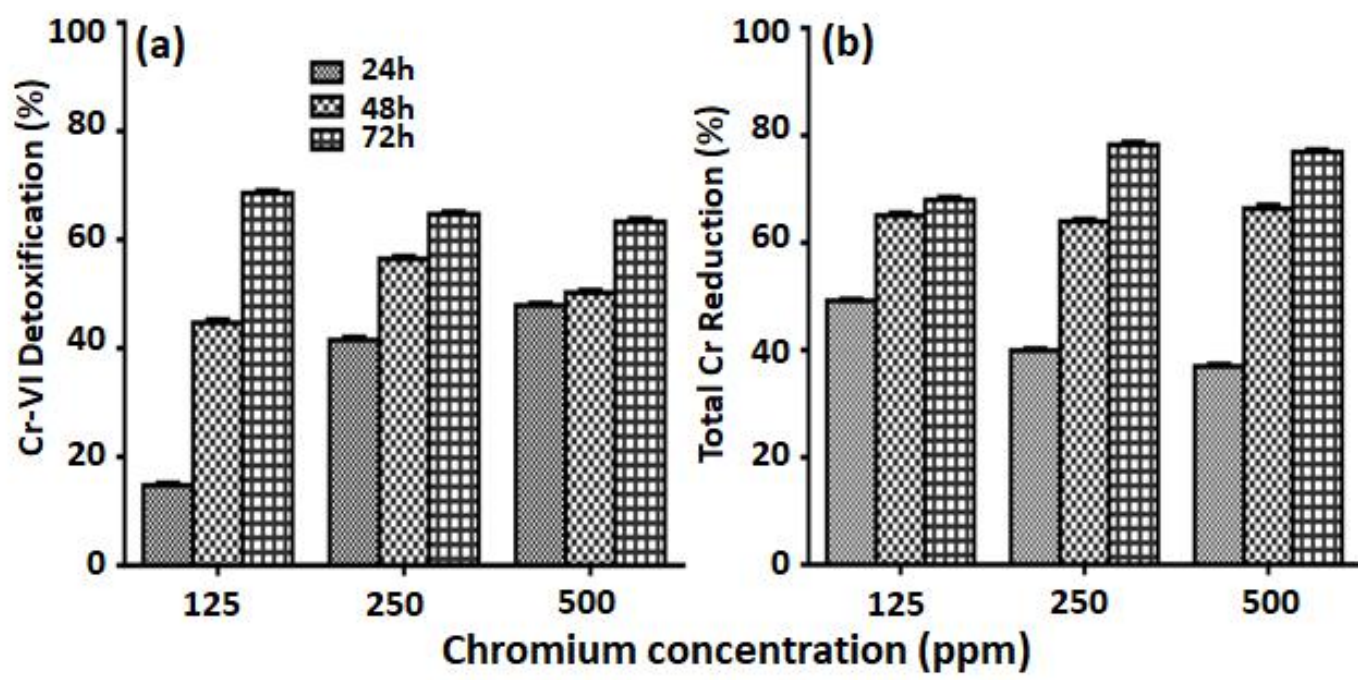

Fig. 6: Detoxification of Cr-VI and reduction of total $\mathrm{Cr}$ as $\mathrm{K}_{2} \mathrm{Cr}_{2} \mathrm{O}_{7}$ by B. carboniphilus. The experiments were conducted by inoculation of minimal salts medium base, $\mathrm{pH} 7$ supplemented with 125,250 and 500 ppm of $\mathrm{K}_{2} \mathrm{Cr}_{2} \mathrm{O}_{7}$ and incubation at $37^{\circ} \mathrm{C}$ for 24,48 and $72 \mathrm{~h}$ followed by measurement of Cr- $\mathrm{VI}$ detoxification (a) by 1,5-diphenylcarbazide colorimetric method and reduction of total $\mathrm{Cr}$ (b) by atomic absorption spectrophotometry.

both pH 7 and 8 (Fig. 10a). The efficiency of detoxification was decreasingly decreased when the $\mathrm{pH}$ of medium was decreased to 6 or 5 . On the other hand, 4 out of 5 isolates exhibited maximum reduction of total $\mathrm{Cr}$ at $\mathrm{pH} 7$ (Fig. 10b). B. subtilis is the only exception that exhibited maximum efficiency of reduction at $\mathrm{pH}$ 8. Likewise, with lowering of $\mathrm{pH}$ to 6 or 5 , the efficiency of reduction of decreasingly decreased.

\section{Carbon Source Dependent Bacterial Detoxification or Reduction of $\mathbf{C r}$}

The effect of carbon source or co-substrate on Cr detoxification or reduction by the bacterial isolates was evaluated by using glucose, peptone or ammonium acetate in the test medium while keeping the concentration of $\mathrm{K}_{2} \mathrm{Cr}_{2} \mathrm{O}_{7}$ as 125 $\mathrm{ppm}$, incubation period as $48 \mathrm{~h}$ and temperature at $37^{\circ} \mathrm{C}$. 


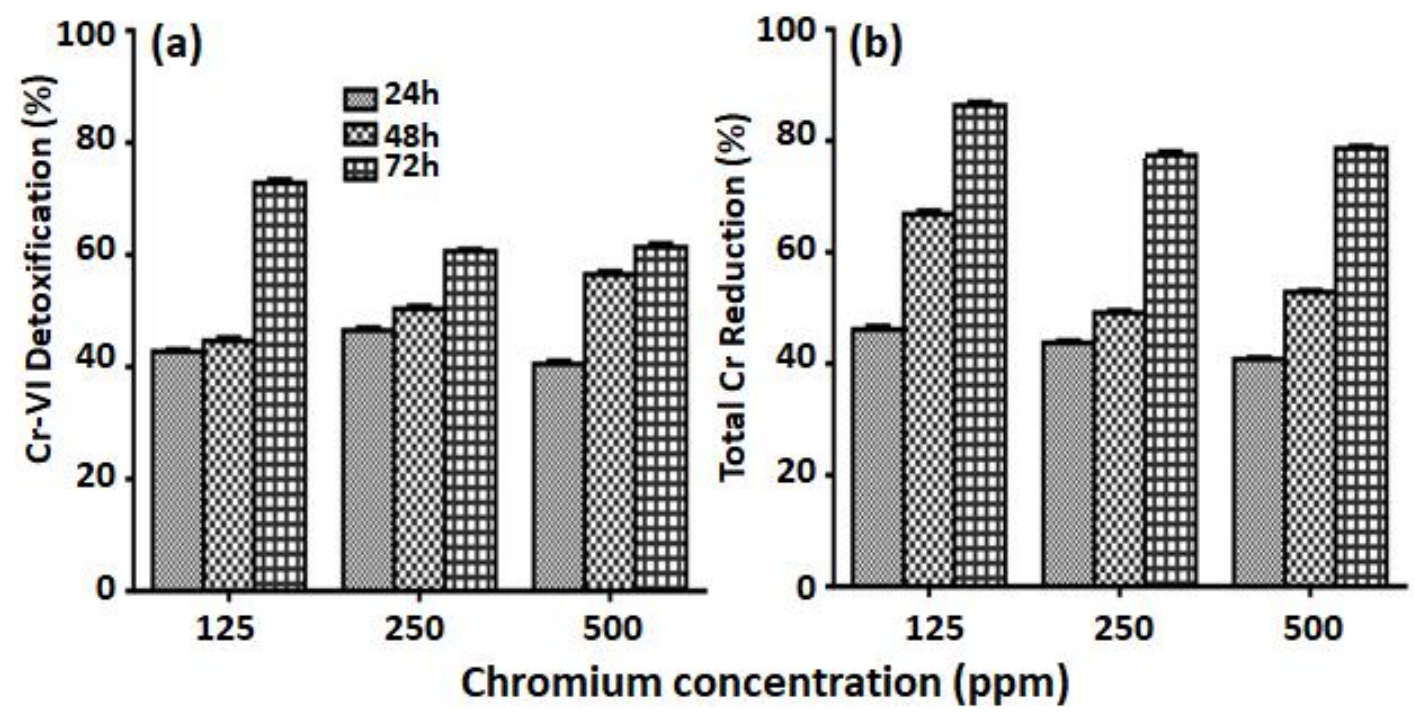

Fig. 7: Detoxification of Cr-VI and reduction of total $\mathrm{Cr}$ as $\mathrm{K}_{2} \mathrm{Cr}_{2} \mathrm{O}_{7}$ by B. licheniformis. The experiments were conducted by inoculation of minimal salts medium base, pH 7 supplemented with 125,250 and 500 ppm of $\mathrm{K}_{2} \mathrm{Cr}_{2} \mathrm{O}_{7}$ and incubation at $37^{\circ} \mathrm{C}$ for 24,48 and $72 \mathrm{~h}$ followed by measurement of Cr- $\mathrm{VI}$ detoxification (a) by 1,5-diphenylcarbazide colorimetric method and reduction of total $\mathrm{Cr}$ (b) by atomic absorption spectrophotometry.

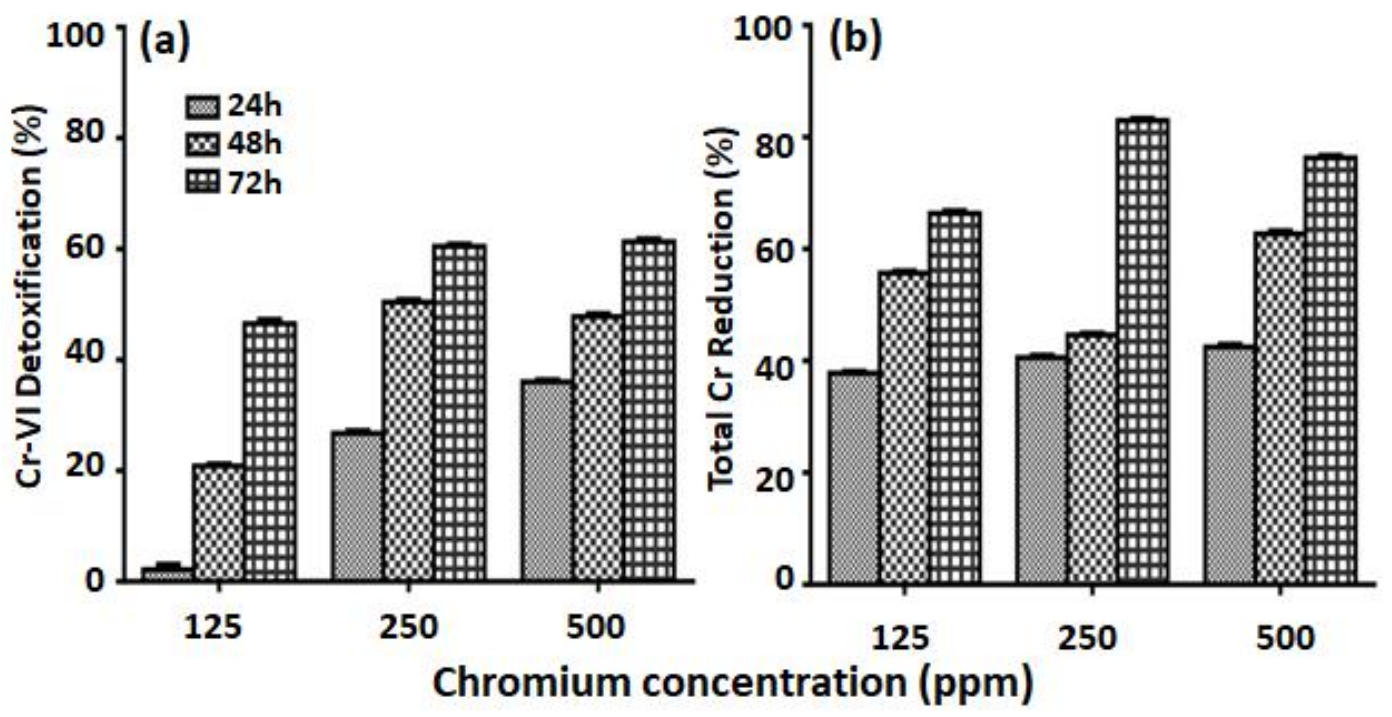

Fig. 8: Detoxification of Cr-VI and reduction of total $\mathrm{Cr}$ as $\mathrm{K}_{2} \mathrm{Cr}_{2} \mathrm{O}_{7}$ by B. subtilis. The experiments were conducted by inoculation of minimal salts medium base, $\mathrm{pH} 7$ supplemented with 125,250 and $500 \mathrm{ppm}$ of $\mathrm{K}_{2} \mathrm{Cr}_{2} \mathrm{O}_{7}$ and incubation at $37^{\circ} \mathrm{C}$ for 24,48 and $72 \mathrm{~h}$ followed by measurement of Cr-VI detoxification (a) by 1,5-diphenylcarbazide colorimetric method and reduction of total $\mathrm{Cr}$ (b) by atomic absorption spectrophotometry.

Notably, 4 among 5 isolates detoxified or reduced $\mathrm{Cr}$ much better in peptone rich medium compared to in glucose or ammonium acetate rich ones. The only exception lied for $B$. megaterium, which exhibited better detoxification of $\mathrm{Cr}-\mathrm{VI}$ in ammonium acetate rich medium but reduction of total $\mathrm{Cr}$ in glucose rich medium (Fig. 11).

\section{Potential of the Isolates in Detoxifying or Reducing $\mathrm{Cr}$ from Tannery Effluent}

In order to evaluate the candidacy of the isolates in detoxifying or reducing $\mathrm{Cr}$ from tannery effluent, freshly collected sample was subjected to bacterial treatment in optimized conditions. Before inoculation, the sample was first sterilized by filtration to nullify the effect of existing microbial population. The $\mathrm{pH}$ of the effluent was adjusted to 7 while inoculated with A. eicrenophila, B. megaterium, $B$. carboniphilus or B. licheniformis. In case of B. subtilis, the $\mathrm{pH}$ was adjusted to 8 . Co-incubation of effluent with bacterial isolates was performed at $37^{\circ} \mathrm{C}$ for $48 \mathrm{~h}$. It is noteworthy that all the isolates exhibited significantly enhanced 

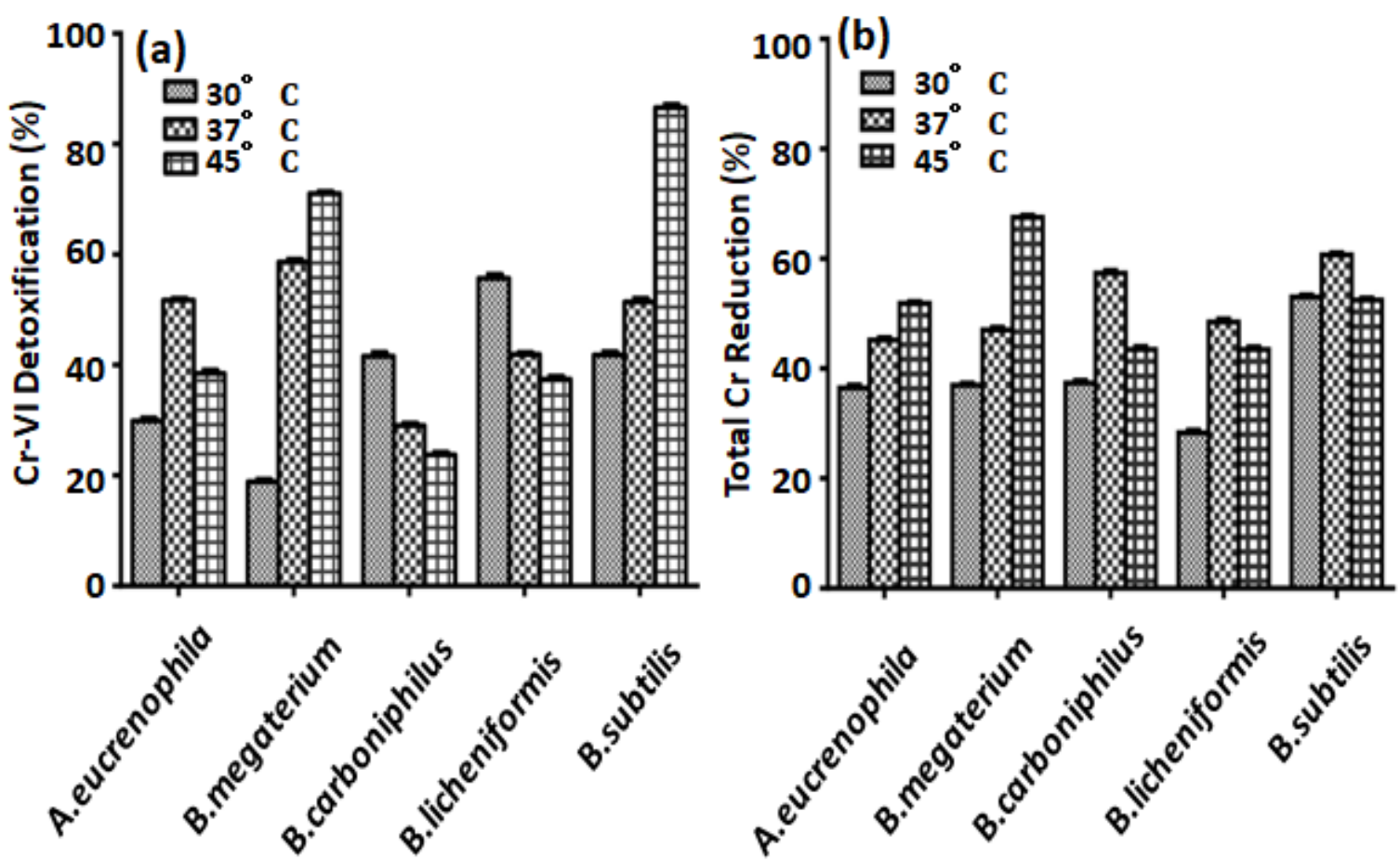

Fig. 9: Detoxification of Cr-VI and reduction of total $\mathrm{Cr}$ as $\mathrm{K}_{2} \mathrm{Cr}_{2} \mathrm{O}_{7}$ by bacterial isolates at 30,37 and $45^{\circ} \mathrm{C}$. The experiments were conducted by inoculation of minimal salts medium base, $\mathrm{pH} 7$ supplemented with $125 \mathrm{ppm}$ of $\mathrm{K}_{2} \mathrm{Cr}_{2} \mathrm{O}_{7}$ and incubation at 37,37 or $45^{\circ} \mathrm{C}$ for $48 \mathrm{~h}$ followed by measurement of Cr-VI detoxification (a) by 1,5-diphenylcarbazide colorimetric method and reduction of total $\mathrm{Cr}$ (b) by atomic absorption spectrophotometry.
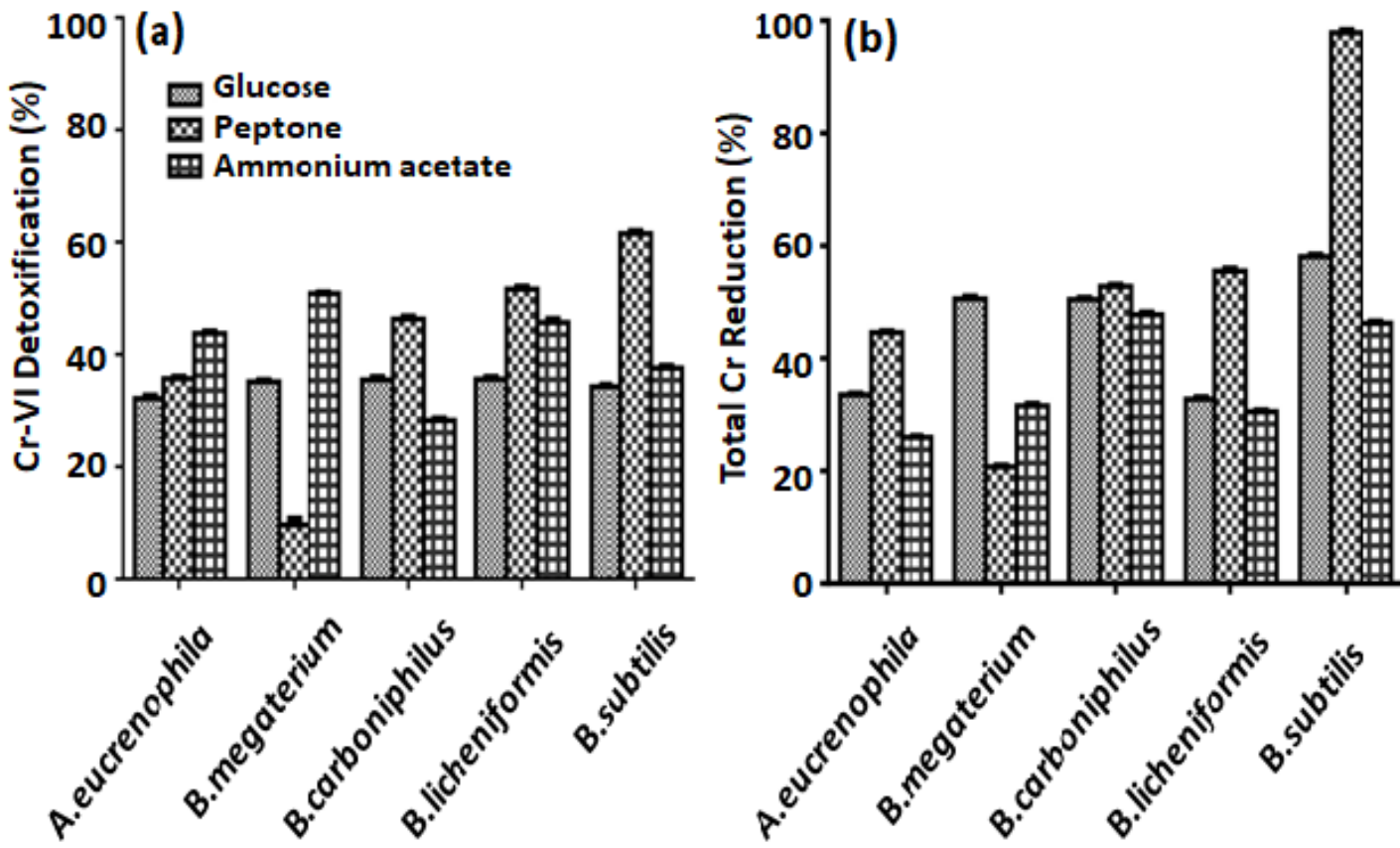

Fig. 10: Detoxification of Cr-VI and reduction of total $\mathrm{Cr}$ as $\mathrm{K}_{2} \mathrm{Cr}_{2} \mathrm{O}_{7}$ by bacterial isolates at $\mathrm{pH} 5,67$ and 8 . The experiments were conducted by inoc-

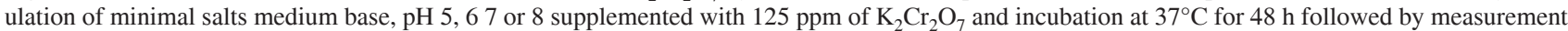
of $\mathrm{Cr}$-VI detoxification (a) by 1,5-diphenylcarbazide colorimetric method and reduction of total $\mathrm{Cr}$ (b) by atomic absorption spectrophotometry. 
(a)

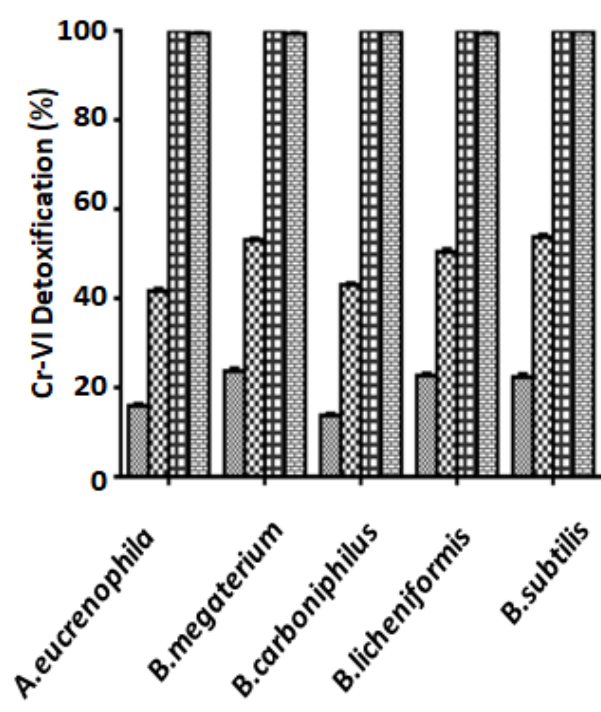

(b)

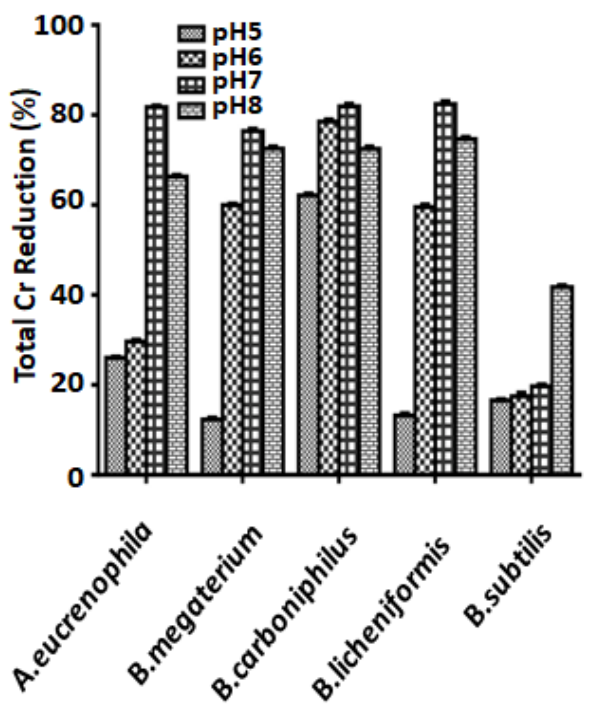

Fig. 11: Detoxification of $\mathrm{Cr}$-VI and reduction of total $\mathrm{Cr}$ as $\mathrm{K}_{2} \mathrm{Cr}_{2} \mathrm{O}_{7}$ by bacterial isolates using glucose, peptone or ammonium acetate as carbon source. The experiments were conducted by inoculation of minimal salts medium base, pH 7 supplemented with 125 ppm of $\mathrm{K}_{2} \mathrm{Cr}_{2} \mathrm{O}_{7}$ and $400 \mathrm{ppm}$ of glucose, peptone or ammonium acetate followed by incubation at $37^{\circ} \mathrm{C}$ for $48 \mathrm{~h}$ and measurement of $\mathrm{Cr}-\mathrm{VI}$ detoxification (a) by 1,5-diphenylcarbazide colorimetric method and reduction of total $\mathrm{Cr}$ (b) by atomic absorption spectrophotometry.

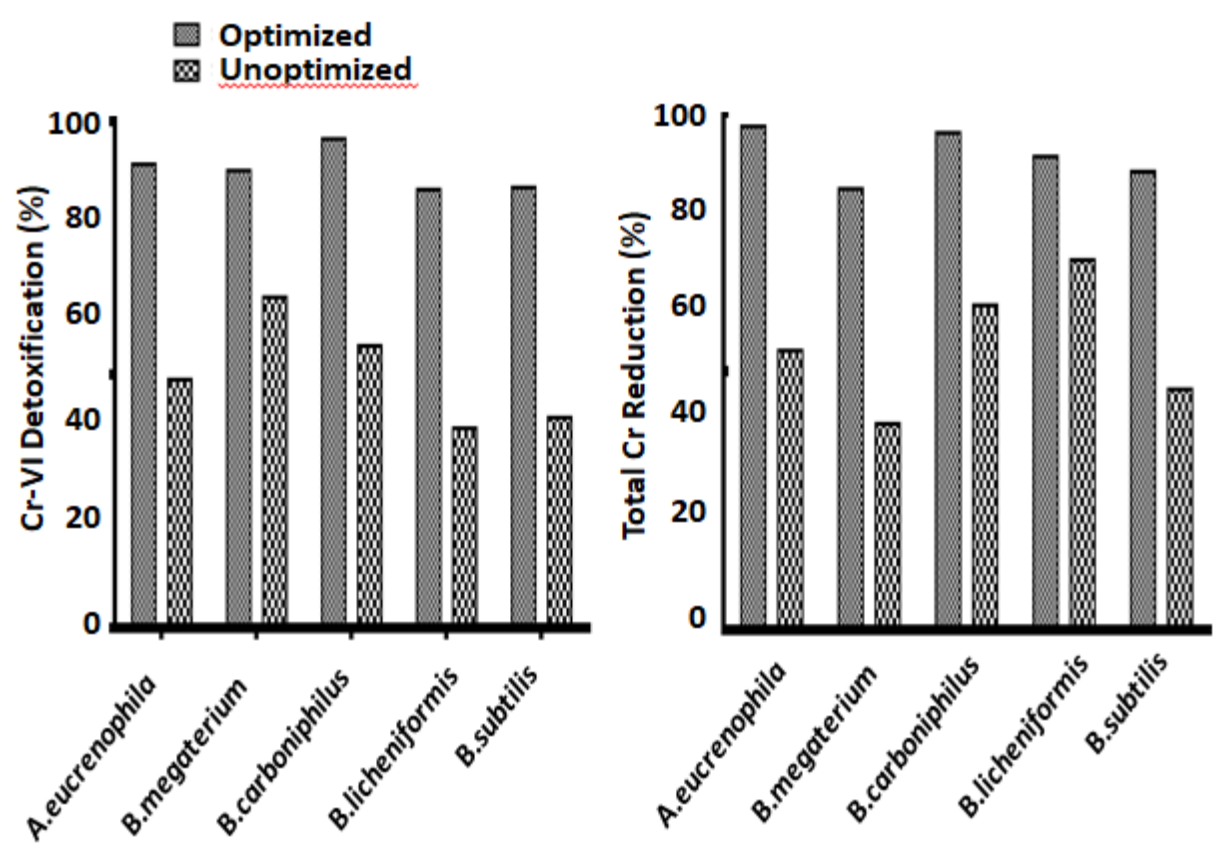

Fig. 12: Detoxification of Cr-VI and reduction of total $\mathrm{Cr}$ from tannery effluent by the isolates in optimized conditions. Freshly collected sample was preconditioned by filtration sterilization followed by $\mathrm{pH}$ adjustment to 7 for A. eicrenophila, B. megaterium, B. carboniphilus or B. licheniformis, and to 8 for $B$. subtilis. The treatment was conducted by inoculation of the preconditioned sample followed by incubation at $37^{\circ} \mathrm{C}$ for $48 \mathrm{~h}$. Initial and final concentration of $\mathrm{Cr}$-VI and total $\mathrm{Cr}$ in the effluent was measured (a) by 1,5-diphenylcarbazide colorimetric method and (b) by atomic absorption spectrophotometry, respectively. The rate of detoxification of $\mathrm{Cr}$-VI and reduction of total $\mathrm{Cr}$ was calculated by subtracting final concentration from initial one, dividing by initial concentration, and multiplying by 100. The result was expressed as percent (\%) of Cr-VI detoxification or total Cr reduction. 
detoxification or reduction of $\mathrm{Cr}$ in optimized conditions compared to their unoptimized counterparts (Fig. 12).

\section{DISCUSSION}

The breakthrough towards the sustainable mitigation of overwhelming pollution caused by the tannery wastewater is installing an efficient, cost-effective, simple and environmentally friendly effluent treatment plant in each industry outlet. From time to time, diverse chemical and biological treatment systems, either independently, subsequently one after another, or in concert, have long been practiced as effective measures in dealing the hazardous effluents. Noticeably, the noble, operative and enduring abilities of naturally occurring bacteria to tolerate and reduce or detoxify heavy metals look the ever-expected and most reliable mean. This concept was the driving force in designing the present study to isolate, identify and optimize environmental conditions of natural bacteria to reduce or detoxify toxic $\mathrm{Cr}$ reside in tannery effluents.

The findings of this study reflect potential candidacy of indigenous and intrinsic bacteria of Aeromonas and Bacillus species in bioremediation of toxic $\mathrm{Cr}$ discharged into the wastewater from tanning industries. Our data clarify that an increased rate of detoxification or reduction was dependent on bacterial growth and exposure time. Our data also delineated the efficiency of the isolates was merely concentration dependent. Noticeably, the efficiency of the isolates increased when the incubation time was increased from 24 to 48 or $72 \mathrm{~h}$. However, the elevated efficiency of most of the isolates over time was predominant up to $48 \mathrm{~h}$. This observation also corresponds to the growth dependent efficiency of the isolates inferring the logarithmic phase of bacterial growth. It is likely that growth of bacteria and damage induced by $\mathrm{Cr}-\mathrm{VI}$ are competing phenomena, where bacteria can adjust with the exposure of $\mathrm{Cr}-\mathrm{VI}$ as long as the sources of metabolizable nutrients are available in the medium. Liu et al. (2006) explained the phenomenon as the bacteria required an increased incubation period for repair or adaptation when exposed to high level of $\mathrm{Cr}-\mathrm{VI}$ in the medium. It has also been suggested that $\mathrm{Cr}-\mathrm{VI}$ induced DNA damage can be repaired by the bacterial SOS function (Oh \& Choi 1997). Growth dependent detoxification or reduction of Cr was also evidenced by Desai et al. (2008). Moreover, the efficiency of most of the isolates was found the utmost at $37^{\circ} \mathrm{C}$ compared to that observed at 30 or $45^{\circ} \mathrm{C}$, which also corresponds to the growth dependent pattern of $\mathrm{Cr}$ detoxification or reduction. Reportedly, the optimal temperature of $\mathrm{Cr}-\mathrm{VI}$ detoxification or total $\mathrm{Cr}$ reduction ranged between 25 and $37^{\circ} \mathrm{C}$ (Cheung \& Gu 2007, Ibrahim et al. 2012). In this study, we also revealed detoxification or reduction of $\mathrm{Cr}$ to be influenced by $\mathrm{pH}$. All the bacterial isolates exhibited their efficiency at neutral or higher $\mathrm{pH}$. In contrast, the efficiency was reversed when the $\mathrm{pH}$ of the medium was lowered to 6 or 5. The efficiency of total $\mathrm{Cr}$ reduction but not of Cr-VI detoxification by $B$. carboniphilus was not much influenced by $\mathrm{pH}$ range tested. Bacterial detoxification of $\mathrm{Cr}$-VI was reported to be significant at pH 6-8 (Wang et al. 1990) and insignificant at $\mathrm{pH} 5$ or 9 (Bopp et al. 1983). Our data thus imply bacterial detoxification or reduction of $\mathrm{Cr}$ is enzyme mediated, since variation of $\mathrm{pH}$ affects the degree of ionization of most of the enzymes, thereby changes conformation of the proteins, and eventually the activity of the enzymes (Farrell \& Ranallo 2000). The growth of the isolates as well as the efficiency of them in detoxifying or reducing $\mathrm{Cr}$ was found greatly influenced when glucose, peptone or ammonium acetate was additionally supplemented in the medium as a direct source of carbon or co-substrate. The co-substrate dependent bacterial efficiency lied on the property of any of the co-substrates as an electron donor for $\mathrm{Cr}$ detoxification or reduction. Our data clearly revealed the utmost detoxification or reduction of $\mathrm{Cr}$ by peptone as co-substrate compared to that by glucose or ammonium acetate. Being expensive, the potential of peptone to be used in an effluent treatment plant is considerably difficult. Ammonium acetate exhibited inconsistent pattern of potency as a co-substrate for the isolates investigated. Glucose, in contrast, exhibiting an optimum range of influence on bacterial detoxification or reduction of $\mathrm{Cr}$, around $60 \%$, seems reliable as a co-substrate. Horitsu et al. (1987) revealed the effect of glucose on the activity of Cr-VI reducing enzyme in Pseudomonas ambigue G-1, which was indeed exerted by completely protecting the enzyme from inactivation on dialysis but not by inducing the activity of the enzyme. Hence, glucose can be considered as co-substrate in Cr bioremediation because of its strong enzyme stabilizing ability.

The present study strongly configured that bacterial detoxification or reduction of $\mathrm{Cr}$ was highly dependent on exposure time and incubating temperature of the reaction as well as the $\mathrm{pH}$ of the medium. Negligible degree of detoxification or reduction was noticed in abiotic control at any time period, temperature and $\mathrm{pH}$ applied, indicating direct interaction of the bacteria in Cr-VI detoxification or total $\mathrm{Cr}$ reduction. When the optimized time, temperature and $\mathrm{pH}$ revealed by in vitro examinations were implemented in detoxifying or reducing $\mathrm{Cr}$ from tannery effluent, the efficiency of the isolates were found significantly increased. Hence, each of the bacterial isolates investigated in this study seems to possess potential as biological agent in $\mathrm{Cr}$ remediation from industrial effluent or contaminated soil or wastewater.

\section{CONCLUSION}

It is the pivotal findings of the present study that the naturally 
occurring bacteria of tannery effluent, namely, Aeromonas eucrenophila, Bacillus megaterium, B. carboniphilus, B. licheniformis and B. subtilis exhibited identical efficiency of detoxifying or reducing $\mathrm{Cr}$. The bacteria also exhibited significant level of resistance or tolerance to greatly increased concentration of $\mathrm{Cr}$. It is noteworthy that the bacteria exerted maximum level of potency at $37^{\circ} \mathrm{C}$ and $\mathrm{pH} 7$ following 48 $h$ of incubation. These environmental or physicochemical parameters closely resemble to the most common or natural conditions of the biological reactor of an effluent treatment plant. Hence, the bacteria isolated, identified and investigated in details in this study possess tremendous potential to be used as biological agents in Cr bioremediation from tannery effluent or $\mathrm{Cr}$ contaminated soil or wastewater of industrial premises.

\section{ACKNOWLEDGMENTS}

The authors express our heartfelt gratitude to Dr. Mala Khan of Designated Reference Institute for Chemical Measurements, Bangladesh Council of Scientific and Industrial Research, Government of the People's Republic of Bangladesh for her generous support in providing laboratory facilities. The study was financed by the Research and Publication Cell of the University of Chittagong, Bangladesh.

\section{REFERENCES}

APHA 1998. Standard Methods for the Examination of Water and Wastewater, 20th ed. American Public Health Association, Washington DC, USA.

APHA, AWWA, WEF 1992. Standard Methods for the Examination of Water and Wastewater. American Public Health Association, American Water Works Association, Water Environmental Federation, Washington DC, USA.

Bibi, R., Arshad, M. and Asghar, H.N. 2012. Optimization of factors for accelerated biodegradation of reactive black-5 azo dye. International Journal of Agricultural Biology, 14: 353-359.

Bopp, L.H, Chakrabarty, A.M. and Ehrlich, H.L. 1983. Chromate resistance plasmid in Pseudomonas fluorescens. Journal of Bacteriology, 155: 1105-1109.

Buchanan, R.E. and Gibbons, N.E. 1974. Bergey's Manual of Determinative Bacteriology, 8th ed. Williams and Wilkins, Baltimore, USA.

Cheung, K.H. and Gu, J.D. 2007. Mechanism of hexavalent chromium detoxification by microorganisms and bioremediation application potential: A review. International Biodeterioration and Biodegradation, 59: 8-15.

Desai, C., Jain, K. and Madamwar, D. 2008, Evaluation of in vitro Cr(VI) reduction potential in cytosolic extracts of three indigenous Bacillus sp. isolated from $\mathrm{Cr}(\mathrm{VI})$ polluted industrial landfill. Bioresearch Technology, 99: 6059-6069.

Farrell, S.O. and Ranallo, R.T. 2000. Experiments in Biochemistry: A Hands-on Approach. Saunders College Publication, Orlando, FL, USA.

Favazzi, A. 2002. Study of the impact of the main policies and environment protection measures in Africa's leather industry. Principal: Assomac Servizi Srl for United Nations Industrial Development Organization.
Flora, S.D., Bagnasco, M., Serra, D. and Zanacchi, P. 1990. Genotoxicity of chromium compounds: A review. Mutation Research, 238: 99-172.

Franco, A.R., Calheiros, C.S.C., Pacheco, C.C., Marco, P.D., Manaia, C.M. and Castro, P.M.L. 2005. Isolation and characterization of polymeric galloyl-ester-degrading bacteria from a tannery discharge place. Microbial Ecology, 50: 550-555.

Gain, P. and Moral, S. 1999. Leather Industry: Environmental pollution and mitigation measures. Society for Environment and Human Development, Dhaka, Bangladesh.

Goodfeelow, G., Herrera, G., Garcia, M.T. and Pena, M. 1994. Bergey's manual of determinative bacteriology, 9th ed. Williams and Wilkins, London, UK.

Horitsu, H., Futo, S., Miyaazawa, Y., Ogai, S. and Kawai, K. 1987. Enzymatic reduction of hexavalent chromium by hexavalent chromium tolerant Pseudomonas ambigua G-1. Agricultural and Biological Chemistry, 47: 2417-2420.

Ibrahim, A.S.S., Elbadawi, B.Y., El-Tayeb, A.M. and Al-Salamah, A.A. 2012. Hexavalent chromium reduction by novel chromate resistant alkaliphilic Bacillus sp. strain KSUCr9a. African Journal of Biotechnology 11(16): 3832-3841.

Liu, Y.G., Xu, W.H., Zeng, G.M., Li, X. and Gao, H. 2006. Cr(VI) reduction by Bacillus sp. isolated from chromium landfill. Process Biochemistry, 41(9): 1981-1986.

Masood, F. and Malik, A. 2011. Hexavalent chromium reduction by Bacillus sp. strain FM1 isolated from heavy-metal contaminated soil. Bulletin of Environmental Contamination and Toxicology, 86: 114-119.

Mondal, N.C., Saxena, V.K. and Singh, V.S. 2005. Impact of pollution due to tanneries on groundwater regime. Current Science, 88(12): 25.

Ogedengbe, K. and Akinbile, C.O. 2004. Impact of industrial pollutants on quality of ground and surface waters at Oluyole industrial estate, Ibadan, Nigeria. Nigerian Journal Technological Development. 4(2): 139-144.

Oh, Y.S. and Choi, S.C. 1997. Reduction of hexavalent chromium by Pseudomonas aeruginosa HP014. Journal of Microbiology, 35: 25-29.

Opperman, D.J. and van Heerden, E. 2008. A membrane-associated protein with $\mathrm{Cr}(\mathrm{VI})$-reducing activity from Thermus scotoductus SA-01. FEMS Microbiology Letter, 280(2): 2108.

Saha, B. and Azam, F.A.B. 2020. Probable ways of tannery's solid and liquid waste management in Bangladesh: An overview and review. Textile and Leather Review, 4(2): 76-95.

Sau, G.B., Chatterjee, S. and Mukherjee, S.K. 2010. Chromate reduction by cell free extract of Bacillus firmus KUCr1. Polish Journal of Microbiology, 59(3): 185-190.

Sobol, Z. and Schiestl, R.H. 2012. Intracellular and extracellular factors influencing $\mathrm{Cr}(\mathrm{VI})$ and $\mathrm{Cr}(\mathrm{III})$ genotoxicity. Environmental and Molecular Mutagenesis 53: 94-100.

Srinath, T., Khare, S. and Ramteke, P.W. 2001. Isolation of hexavalent chromium-reducing $\mathrm{Cr}$ tolerant facultative anaerobes from tannery effluent. Journal of General and Applied Microbiology, 47(6): 307-312.

Sundar, K., Vidya, R., Mukherjee, A. and Chandrasekaranc, N. 2010. High chromium tolerant bacterial strains from Palar river basin: Impact of tannery pollution. Research Journal of Environmental and Earth Sciences, 2(2): 112-117.

Turick, C.E., Apel, W.A. and Carmiol, N.S. 1996. Isolation of Cr(VI) reducing anaerobes from $\mathrm{Cr}$ contaminated and noncontaminated environments. Applied Microbiology and Biotechnology 44: 683-688

Verheijen, L.A.H.M., Wiersema, D. and Hulshoff Pol, L.W. 1996. Livestock and the environment finding a balance: Management of waste from animal product processing. J. De Wit International Agriculture Centre, Wageningen, The Netherlands.

Wang, P.C., Toda, K., Ohtake, H., Kusaka, I. and Yale, I. 1991. Membrane bound respiratory system of Enterobacter cloacaestrain HO1 grown anaerobically with chromate. FEMS Microbiology Letter, 76: 11-16. 